\title{
RENAL LESIONS IN DOGS NATURALLY INFECTED WITH Leishmania
} infantum

\section{ALTERAÇÕES RENAIS DE CÃES NATURALMENTE INFECTADOS COM Leishmania infantum}

\section{Tais Meziara WILSON ${ }^{1}$; Larissa Fernandes MAGALHÃES ${ }^{2}$; Rafael Rocha SOUZA ${ }^{\mathbf{1}}$; Alessandra Aparecida MEDEIROS-RONCHI ${ }^{1}$; Jean Ezequiel LIMONGI ${ }^{3}$}

1. Department of Veterinary Pathology, Faculty of Veterinary Medicine, Federal University of Uberlândia, Uberlândia, MG, Brazil; 2. Departament of Animal Pathology and Clinical Pathology, Faculty of Veterinary Medicine, University of Franca, Franca, SP, Brazil; 3. Geography Institute, Federal University of Uberlândia, Uberlândia, Minas Gerais, Brazil. taismeziara@ gmail.com

\begin{abstract}
We analyzed serum urea and creatinine levels and the renal histology of dogs with canine visceral leishmaniasis, and conducted a urinalysis to evaluate their renal damage. Urine, blood, and kidney samples were obtained from 43 dogs. The dogs were divided into 3 groups according to their clinical presentation: asymptomatic $(n=9)$, oligosymptomatic ( $n=17)$, and symptomatic $(n=17)$. We detected increased creatinine and urea levels in $7 / 43$ and $8 / 43$ of the dogs, respectively. In the urinalysis, nephritis was found in 22/43 seropositive dogs. Histopathologic alterations included tubulointerstitial alterations (39/43) and glomerulonephritis (25/43). Membranoproliferative glomerulonephritis (11/43) was the most common glomerular alteration, followed bymembranous glomerulonephritis (6/43), proliferative glomerulonephritis (7/43), and glomerular sclerosis (1/43). Our data indicate that alterations in the urinalysis and renal histopathology in dogs with leishmaniasis can appear before increases in serum urea and creatinine levels can be detected, even when clinical symptoms of the disease are absent. A diagnosis of leishmaniasis should be considered in dogs with renal damage, and renal function should be evaluated in dogs with leishmaniasis.
\end{abstract}

KEYWORDS: Glomerulonephritis. Histopathological. Kidney. Leishmaniasis. Nephritis.

\section{INTRODUCTION}

Leishmaniasis is an endemic zoonosis caused by flagellate protozoan Leishmania spp. In the Americas, mainly in Brazil, Leishmania infantum causes visceral leishmaniasis (VL) (COLLA-JACQUES; CASANOVA; PRADO, 2010; PALTRINIERI et al., 2010). Dogs are a source of infection for vectors and domestic environments and represent the main link in VL transmission (MELO, 2004; DANTAS-TORRES, 2007). Renal involvement can be the only clinical manifestation of Canine Visceral Leishmaniasis (CVL), presenting as mild proteinuria to nephrotic syndrome. Chronic kidney disease typically develops as the disease progresses and is the main cause of CVL-associated mortality (SOLANOGALLEGO; BANETH, 2012). Renal injury occurs due to immune complex deposition in the glomerulus. It can cause different degrees of nephropathy and renal failure, even in dogs without systemic symptoms (CIARAMELLA et al., 1997; COSTA et al., 2003). Despite its importance the renal changes are still uncertain (ALBUQUERQUE et al., 2008)

Knowledge of the pathological and clinical changes in the kidneys during CVL can be useful for veterinarians to diagnose the disease. Moreover, CVL has been proposed as a model of pathogenesis for human leishmaniasis due the similarities in clinical symptoms and natural progression of the disease (SOARES et al., 2005; SOLANOGALLEGO; BANETH, 2012). The aims of the current study were to evaluate the renal function of CVL-seropositive dogs through biochemical and urinalysis tests and to identify changes in their kidney tissue by histopathology.

\section{MATERIAL AND METHODS}

The current study was approved by the Local Ethics Committee on the Use of Animals $n^{\circ}$ 072/11, CEUA / UFU 034/11 registration protocol. Forty-three dogs that were naturally infected with Leishmania infantum were obtained from the Center for Zoonosis Control. The leishmaniasis diagnosis was confirmed by positive serology in an enzymelinked-immunosorbentassay and indirect immunofluorescence. Animals were submitted to clinical examination and divided into 3 groups: symptomatic, oligosymptomatic, and asymptomatico (BRASIL, 2006).

Urea and creatinine concentrations were determined (KANEKO; HARVEY; BRUSS, 2008) with an automatic analyzer (Chemwell, Awareness Technology Inc) and commercial kits (Labtest Diagnóstica). An acute nephritis diagnosis was defined as albuminuria, the presence of granular 
and/or epithelial cylinders, and a urinary density of maximum $1035 \mathrm{~g} / \mathrm{ml}$. Subacute nephritis was defined as albuminuria, the presence of granular cylinders, and a urinary density between 1015 and $1035 \mathrm{~g} / \mathrm{ml}$. Last, chronic nephritis was defined as the presence of granular, epithelial, or cereus cylinders, and a urinary density below $1015 \mathrm{~g} / \mathrm{ml}$ (BUSH, 1991).

All Leishmania-infected dogs were routinely sacrificed under general anesthesia (using $10 \mathrm{mg} / \mathrm{kg}$ cetamin, $1 \mathrm{mg} / \mathrm{kg}$ xilazin, and $12.5 \mathrm{mg} / \mathrm{kg}$ sodium thiopental) by the Center for Zoonosis Control. Then, a necropsy was performed according to the standard procedure of an animal pathology laboratory. Kidney samples with a volume $1 \mathrm{~cm}^{3}$ were fixed in $10 \%$ formalin, embedded in paraffin, then sectioned and stained with hematoxylin and eosin (HE).

Microscopic glomerular changes were classified as proliferative, membranous, membranoproliferative, and glomeruloesclerosis (CHURG; BERNSTEIN; GLASSOCK, 1995; NEWMAN, 2013). Tubulointerstitial lesions were classified as inflammatory infiltrate, passive hyperemia and fibrosis, tubular degeneration, tubular necrosis, intratubular cylinders, mineralization, and lipofuscin deposition (ALBUQUERQUE et al., 2008). Clinical, laboratory, and histopathologic findings were compared among the groups (symptomatic, oligosymptomatic, and asymptomatic).
The Kruskal-Wallis test was used to determine the average urea and creatinine concentrations ( \pm standard deviations) in the asymptomatic, oligosymptomatic, and symptomatic groups. A binomial test was used to compare the incidence of nephritis and glomerulonephritis within and between the groups, with statistical significance set at $5 \%$.

\section{RESULTS}

Of 43 dogs with leishmaniasis, $20.9 \%(9 / 43)$ were asymptomatic and $39.5 \%$ (17/43) oligosymptomatic. The main clinical symptoms in oligosymptomatic group included lymphadenopathy, weight loss, and opaque fur, whereas they were cutaneous disorders, onychogryphosis, weight loss, and keratitis in the symptomatic group.

Asymptomatic and oligosymptomatic dogs had mean urea and creatinine levels within the normal range, whereas symptomatic dogs had mean values above the reference range for both (Table 1). However, when the increased urea values in the oligosymptomatic and symptomatic groups and the increased creatinine values in all groups (Table 2), were evaluated individually, no statistical significance was observed.

Table 1. Urea and creatinine values of asymptomatic, oligosymptomatic and symptomatic dogs, with canine visceral leishmaniasis.

\begin{tabular}{lcccc}
\hline Laboratory findings & Reference values & Asymptomatic & Oligosymptomatic & Symptomatic \\
\hline Urea $(\mathrm{mg} / \mathrm{dL})$ & $21-60$ & $25,6 \pm 14,9$ & $38,35 \pm 24,82$ & $83,24 \pm 139,3$ \\
Creatinine $(\mathrm{mg} / \mathrm{dL})$ & $0,5-1,5$ & $0,94 \pm 0,32$ & $0,98 \pm 0,34$ & $1,66 \pm 2,12$ \\
\hline
\end{tabular}

Table 2. Levels of urea and serum creatinine in dogs naturally infected by Leishmania spp, according to the clinical manifestation.

\begin{tabular}{llcccccc}
\hline \multirow{2}{*}{ Group } & Level & \multicolumn{2}{c}{$\begin{array}{c}\text { Asymptomatic } \\
(\mathrm{n}=8)\end{array}$} & \multicolumn{2}{c}{$\begin{array}{c}\text { Oligosymptomatic } \\
(\mathrm{n}=15)\end{array}$} & \multicolumn{2}{c}{$\begin{array}{c}\text { Symptomatic } \\
(\mathrm{n}=16)\end{array}$} \\
\cline { 3 - 8 } & & $\mathrm{n}$ & $\%$ & $\mathrm{n}$ & $\%$ & $\mathrm{n}$ & $\%$ \\
\hline \multirow{2}{*}{ Urea } & Normal & 4 & 50 & 7 & 46,6 & 8 & 50 \\
& Raised & 0 & 0 & 4 & 26,6 & 4 & 25 \\
& Diminished & 4 & 50 & 4 & 26,6 & 4 & 25 \\
Creatinine & Normal & 7 & 87,5 & 13 & 86,6 & 9 & 56,2 \\
& Raised & 1 & 12,5 & 1 & 6,6 & 5 & 31,2 \\
& Diminished & 0 & 0 & 1 & 6,6 & 2 & 12,5 \\
\hline
\end{tabular}

Urinalysis, including physical and chemical as well as sediment analyses, was performed in 39 animals. Nephritis was observed in $56.4 \%(22 / 39)$ of CVL-seropositive dogs. Of these, $27.3 \%(6 / 22)$ were asymptomatic, $36.4 \%$ oligosymptomatic, and $36.4 \%$ (8/22) symptomatic. 
Acute nephritis was the most commonly observed type of nephritis, followed by chronic and subacute nephritis. No difference in the manifestation of acute, subacute, or chronic nephritis was detected between the symptomatic, asymptomatic, and oligosymptomatic groups (Table 3).

Table 3. Frequency of nephritis observed in dogs naturally infected with Leishmania chagasi, according to the clinical manifestation

\begin{tabular}{lcccc}
\hline Nephritis type & $\begin{array}{c}\text { Symptomatic } \\
(\mathrm{n}=16)\end{array}$ & $\begin{array}{c}\text { Oligosymptomatic } \\
(\mathrm{n}=15)\end{array}$ & $\begin{array}{c}\text { Asymptomatic } \\
(\mathrm{n}=8)\end{array}$ & Total \\
\hline Acute nephritis & $3(18,7 \%)$ & $6(40,0 \%)$ & $4(50,0 \%)$ & $13(59,1 \%)$ \\
Subacute nephritis & $1(6,2 \%)$ & $2(13,3 \%)$ & $1(12,5 \%)$ & $4(18,2 \%)$ \\
Chronic nephritis & $425,0 \%)$ & $0(0 \%)$ & $1(12,5 \%)$ & $5(22,7 \%)$ \\
\hline
\end{tabular}

Tubular interstitial alterations were observed as the presence of mononuclear inflammatory infiltrate in $60.4 \%(26 / 43)$ of the animals, histioplasmacytic interstitial nephritis in $37.2 \% \quad$ (16/43), lymphoplasmacytic interstitialnephritis in $13.9 \%$ (6/43), and plasmacytic interstitialnephritis in $9.3 \%$ (4/43). Passive hyperemia, tubular degeneration, and tubular necrosis were detected in $37.2 \%$ (16/43), $41.8 \%$ (18/43), and $2.56 \%$ (1/43) of the dogs, respectively. Cylinders were seen in $34.8 \%$ (15/43) of the animals and lipofuscin deposition in tubular cells in $10.2 \%$ (4/43).

Glomerulonephritis was observed in $58.1 \%$ $(25 / 43)$ of the dogs. Membranoproliferative glomerulonephritis (Figure 1 - A) was the most common type (seen in $44.0 \%(11 / 25)$ of the animals). Membranous glomerulonephritis was observed in $24 \%(6 / 25)$ of the animals (Figure 1 B). Proliferative glomerulonephritis was observed in $28 \%(7 / 25)$ of the dogs (Figure $1-\mathrm{C}$ ). Last, glomerular sclerosis (Figure 1 - D) was only found in one symptomati $\operatorname{dog}(4 \%)$.

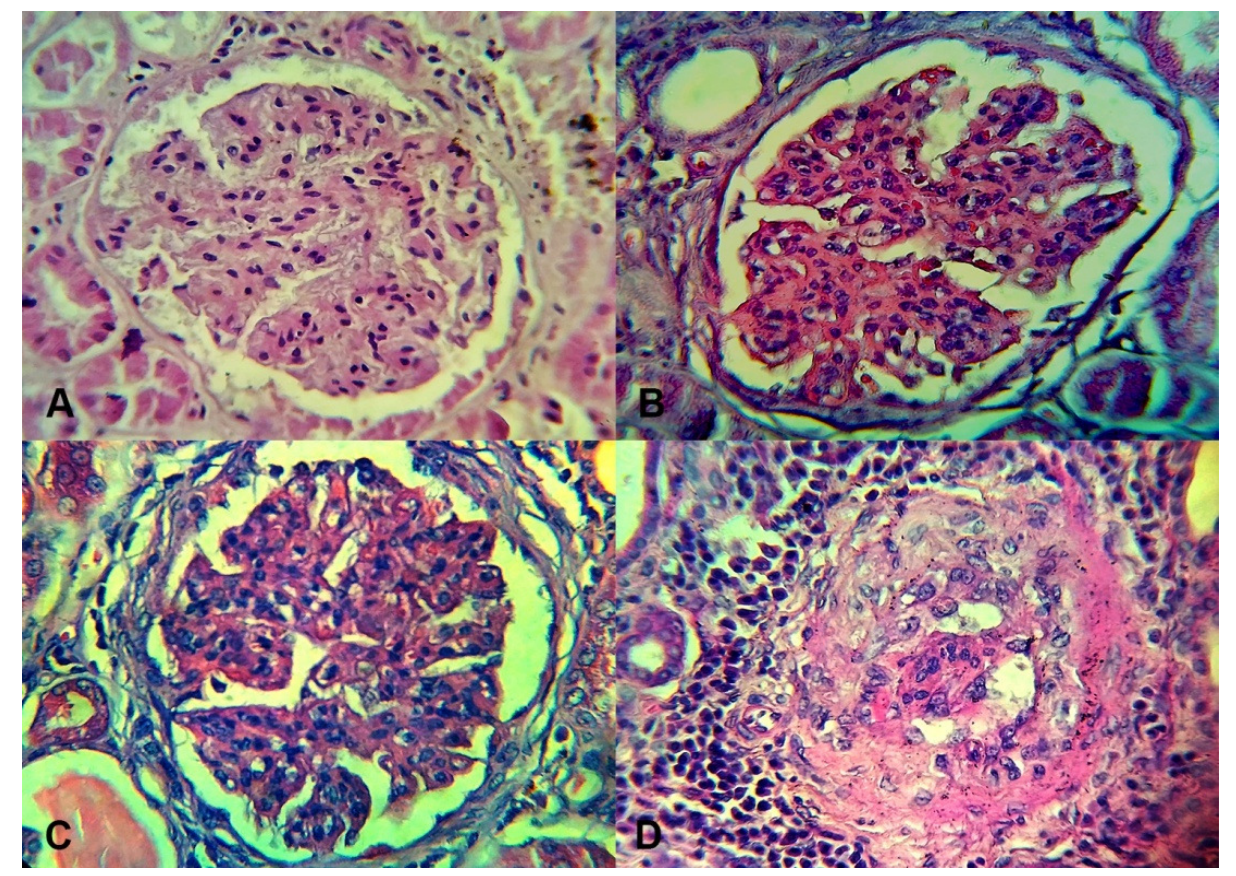

Figure 1. Kidney pattern of glomerulonephritis in dogs with naturally acquired VL. Histopathology (light microscopy). A: Membranous glomerulonephritis. Diffuse glomerular capillary basement membrane thickening. Hematoxylin and eosin. 40x. B: Proliferative glomerulonephritis. Proliferation of endothelial, epithelial, and mesangial cells, causing hypercellularity of the glomerular tufts. Hematoxylin and eosin. 40x. C: Membranoproliferative glomerulonephritis. Hypercellularity following the proliferation of glomerular cells and thickening of the capillary membrane and mesangium. Hematoxylin and eosin. 40x. D: Glomerular sclerosis. Decrease in the hyalinization of glomeruli, an increase in fibrous connective tissue and mesangial matrix, and a loss of glomerular capillaries. Hematoxylin and eosin. 40x. 
Glomerulosclerosis was the least commonly detected type of glomerulonephritis in this study. The binomial test revealed no specific type of glomerulonephritis within each group. There was no statistically significant difference among alterations in the biochemical tests, urinalysis and the histopathology data

\section{DISCUSSION}

In the current study a low frequency of increased serum urea and creatinine levels was found. Measurements of serum creatinine and urea concentrations are useful to evaluate renal injury over time when more than $75 \%$ of kidney function has already been compromised (BELLOMO et al., 2004). Above-normal plasma concentrations of these biochemical parameters have been described as being a common finding in dogs with VL by several authors (SOARES et al., 2005; CARVALHO et al., 2015; COSTA et al., 2015). Renal injury might occur in dogs without systemic clinical manifestations of the disease (CIARAMELLA et al., 1997) which is in agreement with the findings of this study.

On the other hand, urinalysis and analyses of the histological changes to verify kidney damage in our study revealed that $56.4 \%$ (22/39) of the animals had nephritis in the urinalysis. In the microscopic analysis, we found that $60.4 \%$ (26/43) of the dogs had interstitial nephritis and $58.1 \%$ (25/43) glomerulonephritis. However, only 15 dogs were diagnosed by urinalysis and histology concomitantly, and the histological diagnosis was able to detect a larger number of dogs with renal disorders.

CVL has chronic character and has a long incubation period (SOLANO-GALLEGO; BANETH, 2012). This might explain why, a large number of oligosymptomatic and asymptomatic dogs were shown to have nephritis in the urinalysis, with the majority having acute nephritis, whereas the majority of symptomatic animals had chronic nephritis.

Cylindruria was detected in $58.9 \%$ (23/39) of the animals. The condition is associated with a compromised glomerular filtration mechanism, which results in the leakage of glomerular protein and a filtrate containing excess molecules (in particular, proteins) (BUSH, 1991). Regarding the cell type of the interstitial inflammatory infiltrate, previous studies have reported that dogs with CVL show an inflammatory infiltrate containing lymphocytes and plasmocytes (COSTA et al., 2003; ALBUQUERQUE et al., 2008). In dogs with interstitial nephritis, the infiltrate is mainly composed of lymphocytes and histiocytes and rarely contains neutrophils (COSTA et al., 2003). This is consistent with the findings of this study.

Renal injury is caused by the deposition of circulating immune complexes in the basal membrane. This deposition in the glomerulus might result in membranoproliferative glomerulonephritis and interstitial nephritis with impaired renal function. In this study, 58.1\% (25/43) of the dogs had glomerulonephritis, with membranoproliferative being the most common type. Glomerulonephritis incidences have been reported for the membranoproliferative, membranous, focal segmental glomerulosclerotic, and mesangial proliferative disease type (NIETO et al., 1992). However, other authors reported that mesangial proliferative glomerulonephritis was the most common disease type, followed by the membranoproliferative and focal segmental glomerulosclerotic (COSTA et al., 2003).

One symptomatic animal in our study had glomerular sclerosis. This animal also showed interstitial nephritis, the presence of cylinders, and periglomerular fibrosis on histological examination, chronic nephritis in the urinalysis, and high urea and creatinine levels. These changes are characteristic of chronic kidney disease, which possibly manifested as the animal had been infected a long time ago. However, no positive correlation between the changes in the biochemical tests, urinalysis, and the histopathological analysis was found.

Asymptomatic and oligosymptomatic animals can have renal injury although they do not manifest clinical symptoms. Since the severity of the lesions can range from mild to severe, renal function should be evaluated in dogs with VL as these animals might already have acute or chronic nephritis, glomerulonephritis, and even kidney failure, although they might not be showing the clinical symptoms of the disease.

\section{ACKNOWLEDGMENTS}

We thank to the Center for Zoonosis Control of Uberlândia, Uberlândia, Minas Gerais, Brazil. 
RESUMO: Objetivou-se avaliar a função renal de cães sororreagentes para leishmaniose visceral, através da dosagem séricas de ureia e creatinina urinálise e alterações histopatológicas do tecido renal, associando com as alterações clínicas. Foram utilizados 43 cães positivos, divididos em assintomáticos (9/43), oligossintomáticos(17/43) e sintomáticos (17/43). Verificou-se creatina aumentada em 1/9 dos assintomáticos; 1/17 dos oligossintomáticos e 1/17 sintomáticos. 4/17 dos oligossintomáticos e 4/17 dos sintomáticos tiveram valores de ureia aumentados. Constatou-se na urinálise nefrite em 22/43 cães soropositivos, destes 6/22 eram assintomáticos, 8/22 oligossintomáticos e 8/22 sintomáticos. Na avaliação histopatológica verificaram-se alterações tubulointersticiais e glomerulares. A glomerulonefrite membranoproliferativa foi o tipo mais frequente e ocorreu em $11 / 43$ cães sendo que 5/11 eram sintomáticos, 4/11oligossintomáticos e 2/11 eram assintomáticos. Glomerulonefrite membranosa foi observada em 6/43 animais e destes 3/6 eram oligossintomáticos e 3/6 sintomáticos. A glomerulonefrite proliferativa foi observada em 7/43 cães sendo que 3/7 cães eram oligossintomáticos, 2/7 era sintomático e $2 / 7$ eram assintomáticos. A esclerose glomerular foi em 1/43 animal sintomático. A leishmaniose visceral canina pode causar lesões glomerulares e tubulares do tecido renais levando a alterações urinárias e dos valores séricos ureia e creatinina. Cães com leishmaniose podem apresentar lesões renais mesmo sem sinais clínicos da doença.

PALAVRAS-CHAVE: Canino. Rim. Histopatológico. Nefrite. Glomerulonefrites. Leishmaniose.

\section{REFERENCES}

ALBUQUERQUE, B. C. N. C. de; FREDERICO, C. L. M.; JÚNIOR, S.; DA, V. A.; LIMA, A. M. A.; ALBUQUERQUE, E. R. C. de; PIMENTEL, D. de S.; ALVES, L. C. Alterações estruturais em rins de caninos naturalmente infectados por Leishmania (Leishmania) chagasi. Revista Brasileira de Ciência Veterinária, v. 15, n. 1, p. 3-5, abr. 2008. https://doi.org/10.4322/rbcv.2014.187

BRASIL. Ministério da Saúde. Secretaria de Vigilância em Saúde. Departamento de vigilância Epidemiológica. Manual de Vigilância e Controle da Leishmaniose Visceral. Brasília: Ministério da Saúde, 2006.

BUSH, B. M. Interpretation of laboratory results for small animal clinicians. Oxford: Blackwell Scientific Publications, 1991.

CARVAlHO, F. S.; WENCESLAU, A. A.; ALBUQUERQUE, G. R.; MUNHOZ, A. D.; GROSS, E.; CARNEIRO, P. L. S.; OLIVEIRA, H. C.; ROCHA, J. M.; SANTOS, I. A.; REZENDE, R. P. Leishmania (Viannia) Braziliensis in Dogs in Brazil: Epidemiology, Co-Infection, and Clinical Aspects. Genetics and molecular research: GMR, v. 14, n. 4, p. 12062-12073, 2015. https://doi.org/10.4238/2015.October.5.19

CHURG, J.; BERNSTEIN, J.; GLASSOCK, R. J. Renal disease: classification and atlas of glomerular diseases. 2. ed. [s.1.] Igaku-Shoin, 1995.

CIARAMELLA, P.; OLIVA, G.; LUNA, R. D.; GRADONI, L.; AMBROSIO, R.; CORTESE, L.; SCALONE, A.; PERSECHINO, A. A Retrospective Clinical Study of Canine Leishmaniasis in 150 Dogs Naturally Infected by Leishmania Infantum. The Veterinary Record, v. 141, n. 21, p. 539-543, 22 nov. 1997.

https://doi.org/10.1136/vr.141.21.539

COLLA-JACQUES, F. E.; CASANOVA, C.; PRADO, Â. P. do. Study of sand fly fauna in an endemic area of American cutaneous leishmaniasis and canine visceral leishmaniasis in the municipality of Espírito Santo do Pinhal, São Paulo, Brazil. Memórias do Instituto Oswaldo Cruz, v. 105, n. 2, p. 208-215, mar. 2010. https://doi.org/10.1590/S0074-02762010000200017

COSTA, F. a. L.; GOTO, H.; SALDANHA, L. C. B.; SILVA, S. M. M. S.; SINHORINI, I. L.; SILVA, T. C.; GUERRA, J. L. Histopathologic Patterns of Nephropathy in Naturally Acquired Canine Visceral Leishmaniasis. Veterinary Pathology Online, v. 40, n. 6, p. 677-684, 1 nov. 2003. https://doi.org/10.1354/vp.40-6-677

COSTA, M. P.; HORTA, R. S.; COURA, F. M.; DA SILVA MOL, J. P.; VALENTE, P. C. L. G.; PAES, P. R. O. Bioquímica sérica de cães infectados por Ehrlichia canis, Anaplasma platys e Leishmania sp. v. 43, p. $1261,2015$. 
DANTAS-TORRES, F. The Role of Dogs as Reservoirs of Leishmania Parasites, with Emphasis on Leishmania (Leishmania) Infantum and Leishmania (Viannia) Braziliensis. Veterinary Parasitology, v. 149, n. 3-4, p. 139-146, 10 nov. 2007. https://doi.org/10.1016/j.vetpar.2007.07.007

KANEKO, J. J.; HARVEY, J. W.; BRUSS, M. L. Clinical Biochemistry of Domestic Animals. [s.1.] Academic Press, 2008.

MELO, M. N. Leishmaniose visceral no Brasil: desafios e perspectivas. Revista Brasileira de Parasitologia Veterinária, v. 23, n. sup 1, p. 41-45, 2004.

NEWMAN, S. J. The urinary system. In: ZACHARY, J. F., AND MCGAVIN, M. D. Pathologic basis of veterinary disease. 5. ed. St.Louis: Elsevier, 2013. p. 589-653.

NIETO, C. G.; NAVARRETE, I.; HABELA, M. A.; SERRANO, F.; REDONDO, E. Pathological Changes in Kidneys of Dogs with Natural Leishmania Infection. Veterinary Parasitology, v. 45, n. 1-2, p. 33-47, dez. 1992. https://doi.org/10.1016/0304-4017(92)90025-5

PALTRINIERI, S.; SOLANO-GALLEGO, L.; FONDATI, A.; LUBAS, G.; GRADONI, L.; CASTAGNARO, M.; CROTTI, A.; MAROLI, M.; OLIVA, G.; ROURA, X.; ZATELLI, A.; ZINI, E. Guidelines for diagnosis and clinical classification of leishmaniasis in dogs. Journal of the American Veterinary Medical Association, v. 236, n. 11, p. 1184-1191, 1 jun. 2010. https://doi.org/10.2460/javma.236.11.1184

SOARES, M. J. V.; MORAES, J. R. E.; PALMEIRA BORGES, V.; MIYAZATO, L. G.; MORAES, F. R. Renal involvement in visceral leishmaniasis dogs. Journal of Venomous Animals and Toxins including Tropical Diseases, v. 11, n. 4, p. 579-593, dez. 2005. https://doi.org/10.1590/S1678-91992005000400014

SOLANO-GALLEGO, L.; BANETH, G. Leishmaniasis. In: GREENE, C. E. Infectious Diseases of the Dog and Cat. 4. ed. Philadelphia: Elsevier Health Sciences, 2012. p. 734-749. 